\title{
Influence of Stem Cell Therapy on Statin-induced Myopathy of Skeletal Muscle in Female Rats
}

\author{
Dişi Sıçanların İskelet Kasında Statin ile İndüklenen Miyopatide Kök Hücre \\ Tedavisinin Etkisi
}

\author{
Ayat Allah Farouk, Fawzia El-Stoohy*, Sharifa El-Arab Ali*, Hanaa Abd El-Atty*, Leila Rashed**, \\ Noha Abo Krysha***, Shaymaa Mohammed* \\ Cairo University Clinical Faculty of Medicine, Neurophysiology Department, Egypt \\ *al-Azhar University Faculty of Medicine For Girls, Physiology Department, Egypt \\ **Cairo University Faculty of Medicine, Biochemistry Department, Cairo, Egypt \\ ***Cairo University Faculty of Medicine, Neurology Department, Cairo, Egypt
}

\section{Summary}

Objective: This is a trial to visualize the role of transplanted bone marrow mesenchymal stem cells (BM-MSCs) in skeletal muscle regeneration after induction of myopathy using a model of statin induced myopathy.

Material and Method: The study was conducted in eighty female and ten male albino rats, male rats for isolation of MSCs and female rats were divided to 8 groups. Group I was administered $0.5 \%$ carboxymethyl cellulose (solvent), $25 \mathrm{mg} / \mathrm{kg}$ b.w./day, as a control group. Group II was administered simvastatin, $80 \mathrm{mg} / \mathrm{kg}$ b.wt./day, for 16 days, then was sacrificed immediately. Group III was administered simvastatin $80 \mathrm{mg} / \mathrm{kg}$ b.wt/day, for 16 days, and then the rats were sacrificed 14 days after discontinuing simvastatin. Group IV was administered simvastatin $80 \mathrm{mg} / \mathrm{kg}$ b.wt/day for 16 days, then the rats were sacrificed 30 days after discontinuing simvastatin. Group V was administered simvastatin for 30 days, then the rats were sacrificed immediately. Group VI was administered simvastatin for 30 days, with intravenous injection of mesenchymal stem cells on day 16. Group VII was administered simvastatin for 46 days, then the rats were sacrificed immediately. Group VIII was administered simvastatin for 46 days, with intravenous injection of mesenchymal stem cells on day 16. On the morning of the last day of each experimental period needle electromyography (EMG) and nerve conduction (NC) were recorded in gastrocnemius muscle and sciatic nerve. Then rats were sacrificed and blood samples were collected. The gastrocnemius muscles of both limbs were dissected. The right gastrocnemius muscle was processed for histological study and the left one was used for examination of MSCs homing by detection of sry gene using PCR technique. Results: Discontinuing simvastatin 14 and 30 days after induction of myopathy caused marked improvement and regeneration of skeletal muscle as manifested by significant improvement in EMG findings. However, there was persistence of mild myopathic changes after simvastatin cessation, indicating partial recovery. MSCs were injected once on day 16. The transplantation of MSC to myopathic rats, with continuous simvastatin administration, induced significant improvement and regeneration. The improvement recorded in EMG 30 days after MSC injection was significantly better than that observed after 14 days. The light microscopic findings were markedly improved within 14 and 30 days after MSC injection.

Discussion: MSC injection in myopathic rats induced improvement of skeletal muscle function with pronounced regeneration. (Turkish Journal of Neurology 2012; 18:135-144)

Key Words: Mesenchymal stem cells, simvastatin induced myopathy, EMG, female rats

\section{Özet}

Amaç: Bu çalışma, statin ile indüklenen miyopati modeli ile miyopati geliştirilen iskelet kasında, kemik iliği mezenkimal kök hücrelerinin (MKH) kas rejenerasyonundaki etkisini izlemek amacıyla yapılmıştır.

Gereç ve Yöntem: Çalışma 80 dişi ve 10 erkek albino sıçanda yapılmıştır. Erkek sıçanlar mezenkimal kök hücre sağlamak amacı ile kullanılmış, dişi sıçanlar da 8 gruba bölünmüştür. I. Gruba, kontrol grubu olarak 0,5\% karboksimetil sellülöz (çözelti), $25 \mathrm{mg} / \mathrm{kg}$ va./gün uygulanmıştır. II. Gruba 16 gün boyunca 80 $\mathrm{mg} / \mathrm{kg}$ va./gün dozda simvastatin uygulanıp 16. günde kurban edilmişlerdir. III. Gruba $80 \mathrm{mg} / \mathrm{kg}$ va./gün dozda simvastatin 16 gün boyunca verildikten sonra 
sıçanlar ilaç kesilip 14 gün beklenip kurban edilmişlerdir. IV. Gruba $80 \mathrm{mg} / \mathrm{kg}$ va./gün dozda simvastatin 16 gün boyunca verildikten sonra sıçanlar ilaç kesilip 30 gün beklenip kurban edilmişlerdir. V. Gruba simvastatin 30 gün boyunca verilmiştir ve sıçanlar bunun ardından hemen kurban edilmiştir. VI. Gruba Simvastatin 30 gün boyunca verilmiştir ve 16. günde intravenöz MKH enjekte edilmiştir. VII. Gruba 46 gün boyunca simvastatin verilip sıçanlar ardından hemen kurban edilmiştir. VIII. Gruba ise 46 gün boyunca simvastatin verilmiş, 16. günde intravenöz MKH enjekte edilmiştir. Her deney periodunun son gününün sabahında gastrokinemus kası ve siatik sinire iğne elektromiyografisi (EMG) ve sinir ileti çalışmaları (NC) yapılmıştır. Ardından sıçanlar kurban edilip kan örnekleri alınmıştır. Her iki ekstemitenin gastrokinemius kasları diseke edilmiştir. Sağ gastrokinemius kası histolojik çalışma için işleme alınmıştır ve sol gastrokinemius kası PCR tekniği kullanılarak sry gen tespiti ile mezenkimal kök hücrelerin hedef tespiti için kullanılmıştır.

Bulgular: Miyopati indüksiyonu ardından 14 ve 30. günlerde simvastatinin kesilmesi EMG bulgularında belirgin düzelme ile kendini gösterir şekilde iskelet kası rejenerasyonuna yol açmıştır. Buna karşın simvastinin kesilmesine ragmen kısmi iyileşmeye delalet eden hafif miyopatik değişikliklerin devam ettiği de izlenmiştir. Mezenkimal kök hücreler bir kez 16. günde enjekte edilmiştir. Mezenkimal kök hücrelerin halihazırda simvastatin almakta olan miyopatik sıçanlara nakledilmesi belirgin iyileşme ve rejenerasyona yol açmıştır. MKH enjeksiyonundan 30 gün sonra EMG'de kaydedilen iyileşme belirgin olarak 14 gün sonra gözlenenden daha iyidir. Işık mikroskopi bulguları MKH enjeksiyonundan 14 ve 30 gün sonra belirgin olarak daha iyidir.

Sonuç: Miyopatik sıçanlarda mezenkimal kök hücre enjeksiyonu aşikar rejenerasyonla birlikte iskelet kasının işlevinde iyileşme yaratmıştır. (Türk Nöroloji Dergisi 2012; 135-144)

Anahtar Kelimeler: Mezenkimal kök hücreler, simvaststin ile indükelenen miyopati, EMG, dişi sıçanlar

\section{Introduction}

Stem cell research offers great promise for treating a variety of degenerative diseases that currently have no specific or effective treatment $(1,2)$. These include muscular dystrophies for which stem cell therapy is a new hope (3).

Adult stem cells (ASCs) avoid the ethical and immunological concerns of embryonic stem cells (ESCs) $(4,5)$. At the level of skeletal muscle, the resident stem cell population, namely satellite cells, play a major role in skeletal muscle regeneration after its damage by injury or degenerative disease (6). However, the population of the satellite cells in intact skeletal muscle is low. So, it is suggested that stem cells derived from other sources, such as bone marrow stem cells (BMSCs), would participate in the regenerative process of injured skeletal muscle (7). Consequently, bone marrow mesenchymal stem cells (BM-MSCs), by their myogenic potential and their immunomodulatory properties, constitute an attractive candidate for cellular transplantation in cases of diseases associated with muscle dysfunction $(8,9)$.

Statins represent the main therapeutic class of lipid lowering drugs (10). Unfortunately, their therapeutic application can be severely limited by their hazards of inducing myopathy $(11,12)$. Statin myopathy ranges in severity from myalgia and limb weakness to necrosis of skeletal muscle fibres with elevation of serum creatine kinase (ck). (13). On the other hand, discontinuing statin administration usually leads to improvement of the myopathic manifestations (12).

The previous reasons have prompted us to use simvastatin to induce myopathy. Accordingly, we tried to study the role of BMMSC administration on the possible improvement of muscle functions in myopathic rats as indicated by electromyography (EMG), serum ck and serum myoglobin. In addition, this effect will be confirmed by light microscopic study. We take into consideration the reversibility of statin myopathy after drug discontinuation. So, the therapeutic role of MSCs will be studied after induction of myopathy by simvastatin and before its discontinuation (with prolongation of simvastatin administration). We will also study the effect of discontinuing simvatatin after induction of myopathy.

\section{Materials and Methods}

\section{Experimental animals}

We started the study after receiving the approval of the Ethics Committee and followed the guide for the care and use of laboratory animals. In this work, eighty adult female and ten adult male albino rats, aged 6 weeks were used. They were obtained from Helwan Breeding Farm-Cairo, Egypt. Their weights ranged from 150 to $200 \mathrm{~g}$. They were kept under hygienic conditions in an environmentally controlled room (lights on from 5.00 AM to 7.00 PM and temperature range about $27^{\circ}-32^{\circ} \mathrm{C}$ ).

\section{Drugs Used}

Simvastatin powder, purity $98.7 \%$, was kindly provided as a gift from SIGMA Pharmaceutical Company, Egypt. It was administered by oral route using a gastric gavage tube at a dose of $80 \mathrm{mg} / \mathrm{kg}$ body weight (b.wt.)/day. It was formulated for dosing as suspension in water containing $0.5 \%$ Carpoxymethylcellulose (CMC), $25 \mathrm{mg} / \mathrm{kg} \mathrm{b.wt./day.} \mathrm{CMC} \mathrm{was}$ purchased as a powder from El-Nasr Pharmaceutical Chemicals Company, Egypt. The suspension was prepared to dissolve 960 mg simvastatin powder in $60 \mathrm{ml}$ of $0.5 \%$ CMC solution $(960$ $\mathrm{mg} / 60 \mathrm{ml}$ ). A weight related dose was prepared, so that each rat received a dose corresponded to its weight. For example, a rat weighed $200 \mathrm{~g}$ was administered $16 \mathrm{mg}$ simvastatin dissolved in $1 \mathrm{ml}$ of $0.5 \%$ (CMC) solution.

\section{Experimental Design}

Rats were randomly divided to 8 groups, 10 rats each.

Group I:

Rats were administered $0.5 \%$ CMC (solvent), by gastric gavage tube. This group served as a control group.

Group II:

Rats were administered simvastatin, $80 \mathrm{mg} / \mathrm{kg}$ b.wt./day, by gastric gavage tube for 16 days to induce myopathy, then were sacrificed immediately. 


\section{Group III:}

Simvastatin, $80 \mathrm{mg} / \mathrm{kg}$ b.wt./day, was administered by gastric gavage tube for 16 days, then rats were sacrificed 14 days after discontinuing simvastatin.

Group IV:

Simvastatin $80 \mathrm{mg} / \mathrm{kg}$ b.wt./day was administered by gastric gavage tube for 16 days, and then rats were sacrificed 30 days after discontinuing simvastatin.

Group $V$ :

Simvastatin $80 \mathrm{mg} / \mathrm{kg}$ b.wt./day was administered by gastric gavage tube for 30 days, and then rats were sacrificed immediately.

Group VI:

Simvastatin $80 \mathrm{mg} / \mathrm{kg}$ b.wt./day was administered by gastric gavage tube for 30 days, with intravenous injection of mesenchymal stem cells on day 16 .

Group VII:

Simvastatin $80 \mathrm{mg} / \mathrm{kg}$ b.wt./day was administered by gastric gavage tube for 46 days, and then rats were sacrificed immediately.

Group VIII:

Simvastatin $80 \mathrm{mg} / \mathrm{kg}$ b.wt./day was administered by gastric gavage tube for 46 days, with intravenous injection of mesenchymal stem cells on day 16 .

Stem cells were injected, via rat tail vein, once on day 16 in groups VI and VIII (to insure the induction of myopathy). Each rat received $0.5 \mathrm{ml}$ of stem cells (number of cells $=6 \times 106$ ) suspended in phosphate buffer solution (PBS).

On the morning of the last day of each experimental period, needle electromyography (EMG) and nerve conduction (NC) were recorded at Neurophysiology Unit in El-Kasr ELainy hospital, using bipolar needle electrode (H632, NIHON KOHDEN, Japan) and Electromyograph (NIHON KOHDEN, NEUROPACK).

EMG and NC were carried out in gastrocnemius muscle and sciatic nerve, without anesthesia. The rat limbs were tied and fixed except the shaved lower limb in which the needle was inserted. Needle EMG was performed by using a concentric needle electrode.

Thereafter rats were sacrificed by decapitation and blood samples were collected. Then gastrocnemius muscles of both limbs were dissected. The right gastrocnemius was used for tissue histology and the left one was used for examination of MSC homing by detection of sry gene using polymerase chain reaction $(\mathrm{PCR})$ technique.

The blood, collected in centrifuge tubes, was allowed to clot for an hour at room temperature and then centrifuged at 3000 revolutions per minute (rpm) for 15 minutes (using Centurion scientific centrifuge, UK) then sera were separated and stored at $-20^{\circ} \mathrm{C}$ (using -20c REVCO refrigerator) up to the time of use. The separated sera were analyzed for serum $\mathrm{ck}$ and myoglobin.
Tissue Histology:

Gastrocnemius muscles were fixed in buffered $10 \%$ formalin, processed in wax blocks, and then sectioned and stained with haematoxylin and eosin for examination by light microscope.

\section{Preparation of Bone Marrow Derived Mesenchymal Stem} Cells From Male Rats:

Bone marrow was harvested by flushing the tibiae and femurs of 6 weeks old male white albino rats with Dulbecco's modified Eagle's medium (DMEM, GIBCO /BRL) supplemented with $10 \%$ fetal bovine medium (GIBCO/BRL). Nucleated cells were isolated with a density gradient [Ficoll/Paque (Pharmacia)] and resuspended in complete culure medium supplemented with $1 \%$ penicillin-streptomycin (GIBCO/BRL). Cells were incubated at $37^{\circ} \mathrm{C}$ in $5 \%$ humidified $\mathrm{CO} 2$ for $12-14$ days as primary culture. When large colonies developed (80-90\% confluence), cultures were washed twice with PBS and cells were trypsinised with $0.25 \%$ trypsin in 1 $\mathrm{mM}$ EDTA (GIBCO/BRL) for 5 minutes at $37^{\circ} \mathrm{C}$. After centrifugation (at $2400 \mathrm{rpm}$ for 20 minutes), cells were resuspended with serum - supplemented medium and incubated in $50 \mathrm{~cm} 3$ culture flask falcon). The resulting cultures were referred to as first-passage cultures .

MSCs in culture were characterized by their adhesiveness, fusiform shape and by detection of CD 29 one of the surface markers of rat MSCs (14).

Detection of Homing of Male-derived Mesenchymal Stem Cells in the Muscle Tissue by Polymerase Chain Reaction:

The presence or absence of sex determination region on the $\mathrm{Y}$ chromosome male (sry) gene in muscle of recipient female rats was assessed by PCR. Genomic DNA was extracted from muscle tissue homogenate of the rats in each group using Wizard Genomic DNA purification kit (Promega, Madison, WI, USA).

\section{Statistical Analysis}

Statistical analysis was done by using SPSS, version 12. All data were expressed as mean \pm standard error of the mean (S.E.M). The quantitative data were analyzed by One Way Analysis of Variance (ANOVA) with Post-hoc Bonferroni test to evaluate the significance of difference between treated groups. The qualitative data were analyzed by Fisher's Exact test. In all studies a significance of probability value $(\mathrm{p})<0.05$ was considered.

\section{Results}

\section{Nerve Conduction (NC):}

In control group that was received CMC (solvent) all rats showed normal motor NC.

Nerve Conduction in Various Groups:

The motor NC recorded in all studied groups showed normal results in comparison to control.

\section{Electromyography (EMG):}

In control group all rats showed normal EMG findings. The ranges of amplitude and duration were as follows: 
- Range of amplitude: $1.1-2 \mathrm{mv}$.

- Range of duration: $12-12.8 \mathrm{~ms}$.

Effects of Simvastatin Administration and Stoppage for Variable Durations on Electromyography:

The changes in EMG findings with simvastatin administration and discontinuation for variable durations are illustrated in Table 1. Although there was significant improvement in EMG with discontinuation of simvastatin, rats did not return to normal and their mild myopathic changes were significantly different from control $(\mathrm{p}<0.01)$.

Detection of Homing of Male Derived Mesenchymal Stem Cells in the Muscles of Female Rats:

Sry gene that was used as $\mathrm{Y}$ chromosome marker was expressed in myopathic rats that received simvastatin $80 \mathrm{mg} / \mathrm{kg}$ b.wt./day for 30 and 46 days with MSC injection on day 16 (groups VI and VIII, respectively).

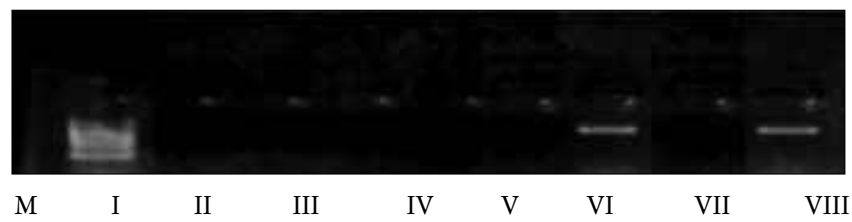

Figure 1. UV transilluminated agarose gel electrophoresis show PCR products of y chromosome (sry) gene in different studied groups.

Lane M: DNA marker with 100 base pair

Lane I, II, III, IV, V, VII:

No PCR products of sry gene

Lane VI, VIII:

PCR products of sry gene
The expression of sry gene by the tissue of the injured muscle of the female rats groups which received male MSC proved homing of the injected cells in the affected muscles (Figure 1).

Effects of Mesenchymal Stem Cells Injection in Myopathic Rats, on Electromyography:

The changes in EMG with MSC injection in myopathic rats are illustrated in Tables 2 and 3.

In spite of improvement of EMG with MSC administration in both groups VI and VIII, the rats did not return to normal and their myopathic changes remained significantly different from control $(\mathrm{p}<0.01)$.

There was also significant improvement in EMG changes after 30 days from MSC injection in group VIII when compared to changes after 14 days from MSC injection in group VI $(\mathrm{p}<0.01)$.

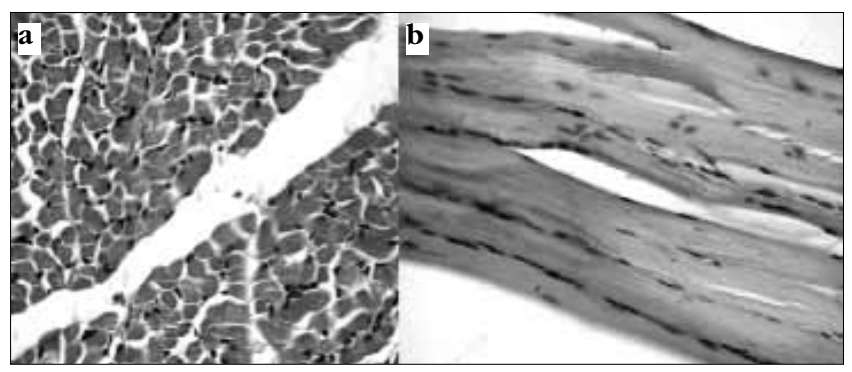

Figure 2. Light microscopic findings in control group. a) Transverse section from gastrocnemius muscle of control (group I), showing polyhedral muscle fibres with flattening of adjacent cells and peripheral location of nuclei. TS, H\&E $\mathrm{X} 400$. b): Longitudinal section from gastrocnemius muscle of control (group I), showing elongated muscle fibres with numerous flattened peripheral nuclei. LS, $\mathrm{H} \& \mathrm{E}$ X 400.

Table 1. Effects of simvastatin administration and discontinuation for variable periods on electromyographic data

\begin{tabular}{|c|c|c|c|c|}
\hline \multirow{2}{*}{$\begin{array}{l}\text { Groups } \\
\text { n=10 rats }\end{array}$} & \multicolumn{4}{|c|}{ Effects of simvastatin administration for variable periods on electromyographic data: } \\
\hline & Normal & Mild myopathy & Moderate myopathy & Severe myopathy \\
\hline Gr. I (control) & $100 \%$ & $0 \%$ & $0 \%$ & $0 \%$ \\
\hline Gr.II (sim. 16 d.) & $0 \%$ & $0 \%$ & $0 \%$ & $100 \%{ }^{\mathrm{a}}$ \\
\hline Gr. V (sim. 30 d.) & $0 \%$ & $0 \%$ & $0 \%$ & $100 \% \mathrm{a}^{\mathrm{a}}$ \\
\hline Gr. VII (sim. 46 d.) & $0 \%$ & $0 \%$ & $0 \%$ & $100 \%{ }^{a}$ \\
\hline
\end{tabular}

Groups $\mathrm{n}=10$ rats

Effects of discontinuing simvastatin in myopathic rats, on electromyograpic data

\begin{tabular}{lcccc} 
& Normal & $\begin{array}{c}\text { Mild myopathy } \\
\text { (marked improvement) }\end{array}$ & $\begin{array}{c}\text { Moderate myopathy } \\
\text { (moderate improvement) }\end{array}$ \\
\hline Gr. I (control) & $100 \%$ & $0 \%$ & $0 \%$ & $0 \%$ \\
Gr. II (sim. 16 d.) & $0 \%$ & $0 \%$ & $0 \%$ & $100 \%{ }^{\mathrm{a}}$ \\
Gr. III (Sim.16d. $\rightarrow$ scr. after 14 d.) & $0 \%$ & $100 \%$ a,b & $0 \%$ & $0 \%$ \\
Gr. IV (Sim.16d. $\rightarrow$ scr. after 30 d.) & $0 \%$ & $100 \%$ a,b & $0 \%$ & $0 \%$
\end{tabular}

\section{Scr $=($ sacrificed $)$}

$\mathrm{a}=\mathrm{P}<0.01$ vs $\mathrm{Gr}$. I (control)

$\mathrm{b}=\mathrm{P}<0.01$ vs Gr. II (Sim. $16 \mathrm{~d}$.)

$\mathrm{n}=$ number of rats in each group

Sim=Simvastatin 


\section{Serum Creatine Kinase (ck) and Serum Myoglobulin:}

Our study showed significant increase in serum ck levels with prolongation of simvastatin, $80 \mathrm{mg} / \mathrm{kg}$ b.wt./day, administration for variable durations $(\mathrm{p}<0.0005)$. These changes are illustrated in Table 4. Discontinuation of simvastatin after induction of

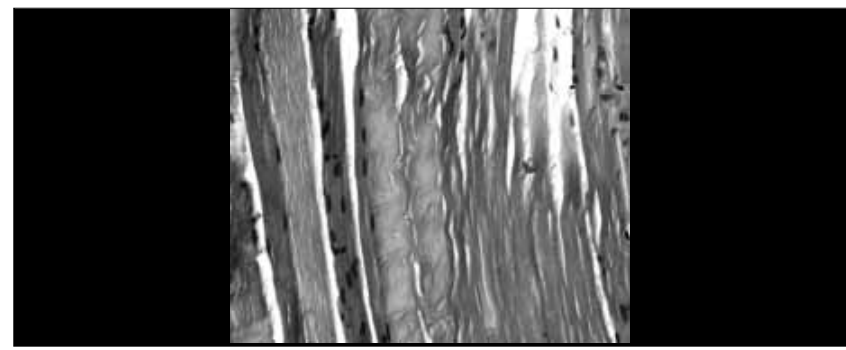

Figure 3. Effect of simvastatin administration for 16 days on light microscopic findings. Longitudinal section from gastrocnemius muscle of group II (sim. 16 days), showing separation of myofibrils, lost striations, enlarged fibres and one with central nucleus. LS, H\&E X 400.

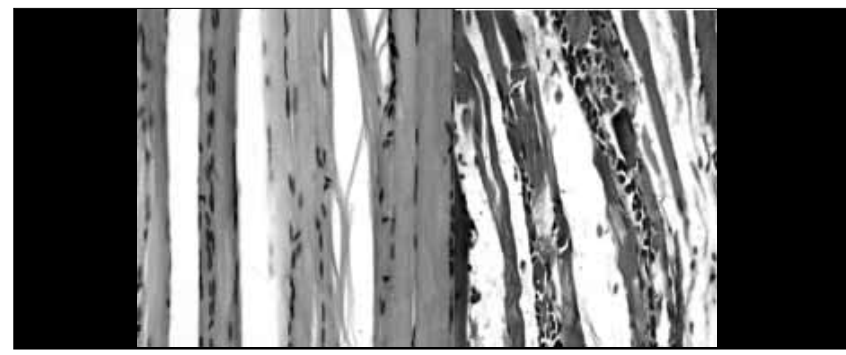

Figure 4. Effect of simvastatin administration for 30 days on light microscopic findings. a) Longitudinal section from gastrocnemius muscle of group V (simvastatin. $30 \mathrm{~d}$.), showing hyper-cellularity and splitting of muscle fibres. LS, $\mathrm{H} \& \mathrm{E} X \mathrm{X} 400 . \mathbf{a}=\mathrm{b}$ ) Longitudinal section from gastrocnemius muscle of group V (simvastatin. 30 d.), destroyed muscle fibres and cellular infiltration. LS, H\&E X 400 . myopathy revealed significant reduction in serum ck levels with levels almost returning normal (Table 5). Serum ck was reduced substantially after MSC injection and ck values returned to normal despite continuous simvastatin administration. These changes are illustrated in Tables 6 and 7.

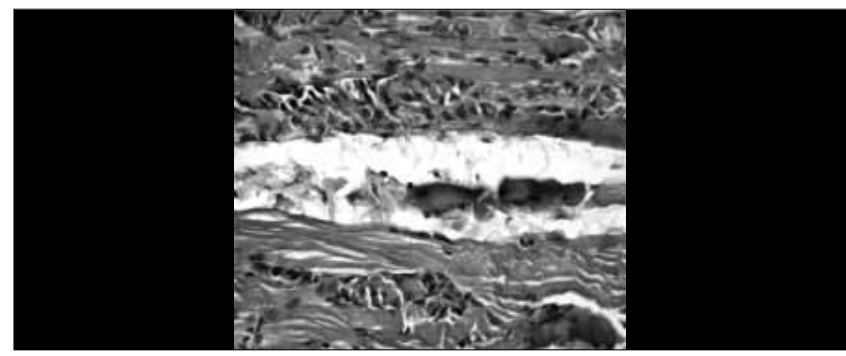

Figure 5. Effect of simvastatin administration for 46 days on light microscopic findings. Longitudinal section from gastrocnemius muscle of group VII (sim. 46 days.), showing massive destruction with lost architecture and cellular infiltration. LS, H\&E X 400.

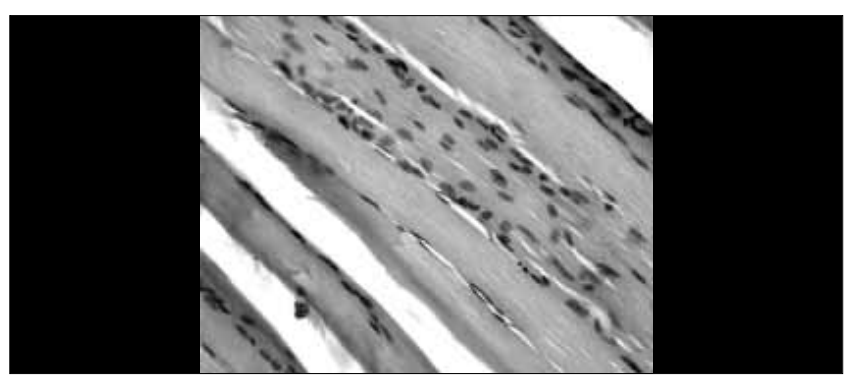

Figure 6. Effect of stoppage of simvastatin administration for 14 days in myopathic rats, on light microscopic findings. Longitudinal section from gastrocnemius muscle of group III (sim.16 d. $\rightarrow$ scr. after 14 d.), showing hypercellularity of muscle fibres with numerous enlarged vesicular nuclei . LS, $\mathrm{H} \& \mathrm{E}$ X 400.

Table 2. Effects of mesenchymal stem cell injection in myopathic rats, on electromyographic data

\begin{tabular}{|c|c|c|c|c|}
\hline \multirow[b]{2}{*}{ Groups $n=10$ rats } & \multicolumn{3}{|c|}{ EMG } & \multirow[b]{2}{*}{ Severe myopathy } \\
\hline & Normal & $\begin{array}{c}\text { Mild myopathy } \\
\text { (marked improvement) }\end{array}$ & $\begin{array}{c}\text { Moderate myopathy } \\
\text { (moderate improvement) }\end{array}$ & \\
\hline Gr. I (Control) & $100 \%$ & $0 \%$ & $0 \%$ & $0 \%$ \\
\hline Gr. V (Sim. 30 d.) & $0 \%$ & $0 \%$ & $0 \%$ & $100 \% \mathrm{a}$ \\
\hline $\begin{array}{l}\text { Gr. VI (Sim. } 30 \text { d. with } \\
\text { MSC at } 16^{\text {th }} \text { d.) }\end{array}$ & $0 \%$ & $0 \%$ & $100 \%$ a,b & $0 \%$ \\
\hline $\begin{array}{l}\text { Gr. VII } \\
\operatorname{sim} .46 \text { d. }\end{array}$ & $0 \%$ & $0 \%$ & $0 \%$ & $100 \% \mathrm{a}$ \\
\hline $\begin{array}{l}\text { Gr. VIII } \\
\text { (Sim. } 46 \text { d with MSC at } 16^{\text {th }} \text { d.) }\end{array}$ & $0 \%$ & $100 \%$ a,c,d & $0 \%$ & $0 \%$ \\
\hline
\end{tabular}

$\mathrm{n}=$ number of rats in each group

$\mathrm{a}=\mathrm{P}<0.01$ vs $\mathrm{Gr}$. I (control)

$\mathrm{b}=\mathrm{P}<0.01$ vs $\mathrm{Gr} . \mathrm{V}$ (sim. $30 \mathrm{~d}$.)

$\mathrm{c}=\mathrm{P}<0.01$ vs $\mathrm{Gr}$. VII (sim. $46 \mathrm{~d}$.)

$\mathrm{d}=\mathrm{P}<0.01$ vs Gr. VI (sim. 30 d. with MSC at $16^{\text {th }}$ d.) 
Prolonged simvastatin administration gave rise to increase in serum myoglobin levels for variable durations $(\mathrm{p}<0.0005)$. These changes are illustrated in table 8 . Discontinuation of simvastatin after induction of myopathy revealed significant reduction in serum myoglobin levels with levels almost returning to normal. These changes are illustrated in table 9. The changes in serum myoglobin with MSCs injection in myopathic rats are illustrated in tables 10 and 11 . Our results showed substantial reduction of serum myoglobin following MSC injection. Myoglobin values almost returned to normal despite continuing simvastatin administration.

\section{Histological Changes}

Light microscopic findings

As shown in figure 2, examination of gastrocnemius muscle sections of control rats treated with cmc (group I) revealed normal skeletal muscle structure. Simvastatin administration for 16 days (group II) caused degenerative changes in muscles, in the form of

\begin{tabular}{|c|c|c|}
\hline \multirow[t]{2}{*}{ Parameter Groups } & \multicolumn{2}{|c|}{ EMG } \\
\hline & $\begin{array}{c}\text { Amplitude (mv) } \\
\text { Mean } \pm \text { S.E.M. }\end{array}$ & $\begin{array}{l}\text { Duration (ms) } \\
\text { Mean } \pm \text { S.E.M. }\end{array}$ \\
\hline Gr. I (Control) & $1.57 \pm 0.13$ & $12.38 \pm 0.12$ \\
\hline Gr. II (Sim. 16 d.) & $0.27 \mathrm{a}_{ \pm} 0.01$ & $5.48^{\mathrm{a}} \pm 0.12$ \\
\hline \multicolumn{3}{|l|}{ Gr. III } \\
\hline (Sim.16d. $\rightarrow$ scr. after 14 d.) & $1.08^{\mathrm{a}, \mathrm{c}} \pm 0.08$ & $9.34^{\mathrm{a}, \mathrm{c}} \pm 0.14$ \\
\hline \multicolumn{3}{|l|}{ Gr. IV } \\
\hline (Sim.16d. $\rightarrow$ scr. after 30 d.) & $0.5^{c, d} d_{ \pm 0.07}$ & $10.8^{b, c, e_{ \pm} 0.26}$ \\
\hline \multicolumn{3}{|l|}{ Gr. V } \\
\hline (Sim. 30 d.) & $0.11^{\mathrm{a}} \pm 0.01$ & $4.15^{a} \pm 0.32$ \\
\hline \multicolumn{3}{|l|}{ Gr. VI } \\
\hline \multicolumn{3}{|l|}{ (Sim. 30 d. with MSC at } \\
\hline $16^{\text {th }} \mathrm{d}$.) & $0.78^{\mathrm{a}, \mathrm{f}} \pm 0.06$ & $22.82^{\mathrm{a}, \mathrm{f}_{ \pm} 0.43}$ \\
\hline \multicolumn{3}{|l|}{ Gr. VII } \\
\hline $\operatorname{sim} .46 \mathrm{~d}$ & $0.06^{\mathrm{a}}{ }_{ \pm 0} .004$ & $4.35^{\mathrm{a}} \pm 0.43$ \\
\hline Gr. VIII & $1.53 \mathrm{~g}, \mathrm{~h}_{ \pm} 0.23$ & $11.07 \mathrm{~g}, \mathrm{~h}_{ \pm 0} 0.16$ \\
\hline \multicolumn{3}{|l|}{ (Sim. $46 \mathrm{~d}$ with } \\
\hline \multicolumn{3}{|l|}{ MSC at $16^{\text {th }}$ d.) } \\
\hline \multicolumn{3}{|l|}{$\mathrm{n}=$ number of rats in each group } \\
\hline \multicolumn{3}{|l|}{ Sim=Simvastatin } \\
\hline \multicolumn{3}{|l|}{ Scr=(sacrificed) } \\
\hline \multicolumn{3}{|c|}{ By ANOVA: Amplitude: $F=141,7, P<0.0005$} \\
\hline \multicolumn{3}{|c|}{ By Bonferroni Test: } \\
\hline \multicolumn{3}{|l|}{$\mathrm{a}=\mathrm{P}<0,0005$ vs Gr.I (control) } \\
\hline \multicolumn{3}{|l|}{$\mathrm{b}=\mathrm{P}<0,05$ vs Gr.I (control) } \\
\hline \multicolumn{3}{|c|}{$c=P<0,0005$ vs Gr.II (sim. 16 d.) } \\
\hline \multicolumn{3}{|c|}{$\mathrm{d}=\mathrm{P}<0,01$ vs Gr.II (sim. $16 \mathrm{~d} . \rightarrow$ scr. after $14 \mathrm{~d}$.) } \\
\hline \multicolumn{3}{|c|}{$\mathrm{e}=\mathrm{P}<0,05$ vs Gr.II (sim. $16 \mathrm{~d} . \rightarrow$ scr. after 14 d.) } \\
\hline \multicolumn{3}{|c|}{$f=P<0,0005$ vs $\mathrm{Gr} . \mathrm{V}$ (sim. 30 d.) } \\
\hline \multicolumn{3}{|l|}{$\mathrm{g}=\mathrm{P}<0,0005$ vs Gr.VII (sim. 46 d.) } \\
\hline $\mathrm{h}=\mathrm{P}<0,0005$ vs Gr.VI (sim. 30 d. w & SC at $16^{\text {th }}$ d.) & \\
\hline
\end{tabular}

lost cross striations, separation of myofibrils, enlarged edematous muscle fibres and central nucleation (Figure 3). Simvastatin administration for 30 days (group V) resulted in more degeneration (Figure 4a) and some reached to the extent of

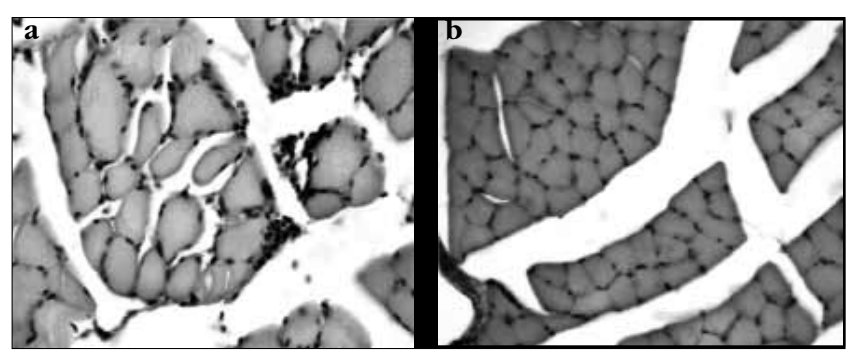

Figure 7. Effect of stoppage of simvastatin administration for 30 days in myopathic rats, on light microscopic findings. a) Transverse section from gastrocnemius muscle of group IV (sim.16 d. $\rightarrow$ scr. after $30 \mathrm{~d}$.), showing hypercellularity with marked increased nuclei. TS, H\&E X 400 b) Transverse section from gastrocnemius muscle of group IV (sim.16 d. $\rightarrow$ scr. after $30 \mathrm{~d}$.), showing almost normal muscle fibres with marked increased nuclei . TS, H\&E X 400

Table 4. Effects of simvastatin administration for variable periods, on serum creatine kinase $(\mathrm{u} / \mathrm{l})$

\begin{tabular}{lcc}
\hline Groups $n=10$ rats & \multicolumn{2}{c}{ Serum ck (u/l) } \\
& Mean \pm S.E.M & $\%$ change \\
\hline Gr.I Control & $307.3 \pm 15.9$ & \\
Gr.II (sim. 16 d.) & $590.8^{\mathrm{a}} \pm 45.9$ & $+92.3 \%$ \\
Gr. V (sim. 30 d.) & $691.6^{\mathrm{a}} \pm 57$ & $+125 \%$ \\
Gr. VII (sim. 46 d.) & $846.1^{\mathrm{a}, \mathrm{b}} \pm 65.8$ & $+175.3 \%$ \\
& & $+43.2 \%$ \\
\hline
\end{tabular}

$\mathrm{n}=$ number of rats in each group

By ANOVA: $\mathrm{F}=20.8, \mathrm{P}<0.0005$

By Bonferroni Test:

$\mathrm{a}=\mathrm{P}<0.0005$ vs $\mathrm{Gr}$. I (control)

$\mathrm{b}=\mathrm{P}<0.0005$ vs $\mathrm{Gr}$. II (sim.16 d.)

Table 5. Effects of discontinuing simvastatin in myopathic rats, on serum creatine kinase $(\mathrm{u} / \mathrm{l})$

\begin{tabular}{|c|c|c|}
\hline \multirow[t]{2}{*}{ Groups $n=10$ rats } & \multicolumn{2}{|c|}{ Serum ck $(\mathrm{u} / \mathrm{l})$} \\
\hline & Mean \pm S.E.M & $\%$ change \\
\hline Gr. I Control & $307.3 \pm 15.9$ & \\
\hline Gr. II (sim. 16 d.) & $590.8^{a} \pm 45.9$ & $+92.3 \%$ \\
\hline \multicolumn{3}{|l|}{ Gr. III } \\
\hline (Sim.16 d. $\rightarrow$ sacr. after 14 d.) & $373.6^{\mathrm{b}} \pm 37.1$ & $-36.8 \%$ \\
\hline \multicolumn{3}{|l|}{ Gr. IV } \\
\hline (Sim.16 d. $\rightarrow$ sacr. after 30 d.) & $323.6^{c} \pm 22.3$ & $-45.23 \%$ \\
\hline \multicolumn{3}{|l|}{$\mathrm{n}=$ number of rats in each group } \\
\hline \multicolumn{3}{|l|}{ Sim $=$ Simvastatin } \\
\hline \multicolumn{3}{|l|}{ Scr $=($ sacrificed $)$} \\
\hline \multicolumn{3}{|l|}{ By ANOVA: $\mathrm{F}=13.2, \mathrm{P}<0.0005$} \\
\hline \multicolumn{3}{|l|}{ By Bonferroni Test: } \\
\hline \multicolumn{3}{|l|}{$\mathrm{a}=\mathrm{P}<0.0005$ vs Gr. I (control) } \\
\hline \multicolumn{3}{|l|}{$\mathrm{b}=\mathrm{P}<0.05$ vs Gr. II (sim. $16 \mathrm{~d}$.) } \\
\hline$c=\mathrm{P}<0.01$ vs Gr. II (sim. 16 d.) & & \\
\hline
\end{tabular}


complete destruction of the muscle fibres with cellular infiltration (Figure $4 \mathrm{~b}$ ). Simvastatin administration for 46 days (group VII) caused the most extreme state of degeneration when compared to the other groups. Degeneration extended to massive destruction with dramatic losing of muscle architecture (Figure 5).

After discontinuing simvastatin, after 14 days (group III) and 30 days (group IV), there was improvement in the light microscopic findings when compared to those of myopathic rats that were administered simvastatin for 16 days (group III) (Figure 6, 7).

Table 6. Effect of mesenchymal stem cells after 14 days from injection in myopathic rats, on serum creatine kinase (u/l)

\begin{tabular}{lcc}
\hline Groups $\mathrm{n}=10$ rats & \multicolumn{2}{c}{ Serum CK (U/L) } \\
& Mean \pm S.E.M & $\%$ change \\
\hline Gr. I (Control) & $307.3 \pm 15.9$ & \\
Gr. V (Sim. 30 d.) & $691.6^{a} \pm 57$ & $+125 \%$ \\
Gr. VI & & \\
(Sim. 30 d. with MSC at & $354.9^{\mathrm{b}} \pm 33.1$ & $-48.7 \%$ \\
$16^{\text {th }}$ d.) & & \\
\hline $\mathrm{n}=$ number of rats in each group & \\
By ANOVA: $\mathrm{F}=34.3, \mathrm{P}<0.0005$ & \\
By Bonferroni Test: & \\
$\mathrm{a}=\mathrm{p}<0.0005$ vs Gr. I (control) & \\
$\mathrm{b}=\mathrm{p}<0.0005$ vs Gr. V (sim. 30 d.) &
\end{tabular}

Table 7. Effect of mesenchymal stem cells after 30 days from injection in myopathic rats on serum creatine kinase $(\mathrm{u} / \mathrm{l})$

\begin{tabular}{lcc}
\hline Groups $\mathrm{n}=10$ rats & \multicolumn{2}{c}{ Serum CK (U/L) } \\
& Mean \pm S.E.M & $\%$ change \\
\hline Gr. I Control & $307.3 \pm 15.9$ & \\
Gr. VII sim.46 d. & $846.1^{\mathrm{a}} \pm 65.8$ & $+175.3 \%$ \\
Gr. VIII (Sim. 46 d with MSC at & & \\
$16^{\text {th }}$ d.) & $323^{\mathrm{b}} \pm 26.3$ & $-61.8 \%$ \\
\hline $\mathrm{n}=$ number of rats in each group & & \\
Sim=Simvastatin & \\
Scr=(sacrificed) & \\
By ANOVA: $\mathrm{F}=61.5, \mathrm{P}<0.0005$ & \\
By Bonferroni Test: & \\
$\mathrm{a}=\mathrm{p}<0.0005$ vs Gr. $\mathrm{I}(\mathrm{cmc})$ & \\
$\mathrm{b}=\mathrm{p}<0.0005$ vs Gr. VII (sim. 46 d.) & \\
\hline
\end{tabular}

Table 8. Effects of simvastatin administration, for variable durations, on serum myoglobin $(\mathrm{ng} / \mathrm{ml})$

\begin{tabular}{lcc}
\hline Groups $\mathbf{n}=10$ rats & \multicolumn{2}{c}{ Serum myoglobin $(\mathrm{ng} / \mathrm{ml})$} \\
& Mean \pm S.E.M & $\%$ change \\
\hline Gr.I (control) & $0.13 \pm 0.008$ & \\
Gr.II (sim. 16 d.) & $0.34^{\mathrm{a}_{ \pm} 0.014}$ & $+170 \%$ \\
Gr. V (sim. 30 d.) & $0.79^{\mathrm{a}, \mathrm{b}} \pm 0.059$ & $+518.7 \%$ \\
& & $+129.2 \%$ \\
Gr. VII (sim. 46 d.) & $0.83^{\mathrm{a}, \mathrm{b}} \pm 0.064$ & $+552.4 \%$ \\
& & $+141.7 \%$ \\
\hline
\end{tabular}

$\mathrm{n}=$ number of rats in each group

By ANOVA: $F=93.6, P<0.0005$

By Bonferroni Test:

$\mathrm{a}=\mathrm{P}<0.0005$ vs Gr. I (control)

$\mathrm{b}=\mathrm{P}<0.0005$ vs Gr. II (sim. $16 \mathrm{~d}$.)
MSC therapy resulted in great improvement in light microscopic findings of myopathic rats, either after 14 days (group VI) or 30 days (group VIII) with greater improvement in the latter (Figure 8, 9).

\section{Discussion}

Statins are widely used to reduce plasma cholesterol levels (15). However, statin therapy can be severely limited by its adverse effects, especially myopathy (11). The present study showed that administration of simvastatin, $80 \mathrm{mg} / \mathrm{kg}$ b.wt./day,

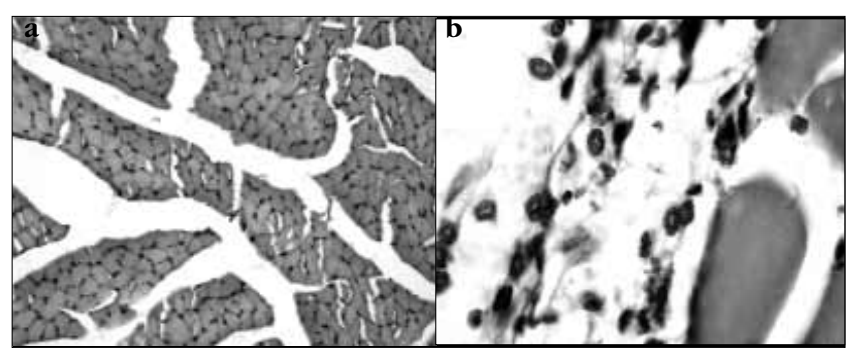

Figure 8. Effect of mesenchymal stem cells after 14 days from injection in myopathic rat, on light microscopic findings. a) Transverse section from gastrocnemius muscle of group VI (sim. $30 \mathrm{~d}$. with MSC on day 16), showing almost normal muscle fibres with hypercellularity. TS, H\&E X 200. b) Transverse section from gastrocnemius muscle of group VI (sim. 30 d. with MSC on day 16), showing numerous neutrophils (arrow). TS, H\&E X 1000

Table 9. Effects of discontinuing simvastatin in myopathic rats, on serum myoglobin ( $\mathrm{ng} / \mathrm{ml}$ )

\begin{tabular}{|c|c|c|}
\hline \multirow[t]{2}{*}{ Groups $n=10$ rats } & \multicolumn{2}{|c|}{ Serum myoglobin $(\mathrm{ng} / \mathrm{ml})$} \\
\hline & Mean \pm S.E.M & $\%$ change \\
\hline Gr. I (control) & $0.13 \pm 0.008$ & \\
\hline Gr. II (sim. 16 d.) & $0.34^{\mathrm{a}} \pm 0.014$ & $+170 \%$ \\
\hline Gr. III & & \\
\hline (Sim.16 d. $\rightarrow$ sacr. after 14 d.) & $0.14^{\mathrm{b}} \pm 0.009$ & $-59.2 \%$ \\
\hline $\begin{array}{l}\text { Gr. IV } \\
(\text { Sim.16 d. } \rightarrow \text { sacr. after } 30 \text { d.) }\end{array}$ & $0.13^{\mathrm{b}} \pm 0.012$ & $-61.5 \%$ \\
\hline $\mathrm{n}=$ number of rats in each group & & \\
\hline By ANOVA: $\mathrm{F}=83.8, \mathrm{P}<0.0005$ & & \\
\hline By Bonferroni Test: & & \\
\hline $\mathrm{a}=\mathrm{P}<0.0005$ vs Gr. I (control) & & \\
\hline $\mathrm{b}=\mathrm{p}<0.0005$ vs Gr. II (sim.16 d.) & & \\
\hline
\end{tabular}

Table 10. Effect of mesenchymal stem cells after 14 days from injection in myopathic rats, on serum myoglobin $(\mathrm{ng} / \mathrm{ml})$

\begin{tabular}{lcc}
\hline Groups $\mathrm{n}=10$ rats & \multicolumn{2}{c}{ Serum myoglobin $(\mathrm{ng} / \mathrm{ml})$} \\
& Mean \pm S.E.M & $\%$ change \\
\hline Gr. I (control) & $0.13 \pm 0.008$ & \\
Gr. V (Sim. 30 d.) & $0.79^{\mathrm{a}} \pm 0.059$ & $+518.7 \%^{\mathrm{a}}$ \\
Gr. VI & & \\
(Sim. 30 d. with MSC at $16^{\text {th }}$ d.) & $0.14^{\mathrm{b}} \pm 0.014$ & $-82.2 \% \mathrm{~b}$ \\
\hline $\mathrm{n}=$ number of rats in each group & \\
By ANOVA: $\mathrm{F}=137.2, \mathrm{P}<0.0005$ & \\
By Bonferroni Test: \\
$\mathrm{a}=\mathrm{P}<0.0005$ vs Gr. I (control) \\
$\mathrm{b}=\mathrm{P}<0.0005$ vs. Gr. V (sim. 30 d.)
\end{tabular}


caused severe myopathy in rats. This was accompanied by a significant increase in serum $\mathrm{ck}$ and serum myoglobin levels after 16, 30 and 46 days of simvastatin administration. There were also light microscopic degenerative changes in the gastrocnemius muscle that were more apparent with prolonged duration of simvastatin administration. The degenerative changes ranged from enlargement of muscle fibres with splitting and lost striations to complete destruction with lost architecture and cellular infiltration. Degeneration process was accompanied by regeneration in the form of hypercellularity and increased nuclei.

Westwood et al. (16) induced myopathy in female rats by using maximum tolerable dose (MTD) of simvastatin $(80 \mathrm{mg} / \mathrm{kg}$ b.wt/day). From day 12 to day 16 there was significant increase in serum ck levels and a variable severity and distribution of muscle fibre necrosis. These results were confirmed by Sidaway et al. (17) and Mallinson et al. (18). Significant elevation of serum ck and serum myoglobin was also reported by Pierno et al. (19), with rats chronically treated with fluvastatin $20 \mathrm{mg} / \mathrm{kg}$ b.wt./day and atorvastatin $10 \mathrm{mg} / \mathrm{kg}$ b.wt./day for 2 months, and there was no histological sign of muscle damage. Pierno et al. (11) used the same doses of both fluvastatin and atorvastatin and reported needle EMG changes, where some rats showed spontaneous electrical activity with no myopathic changes in all. The difference in histological picture and needle EMG findings

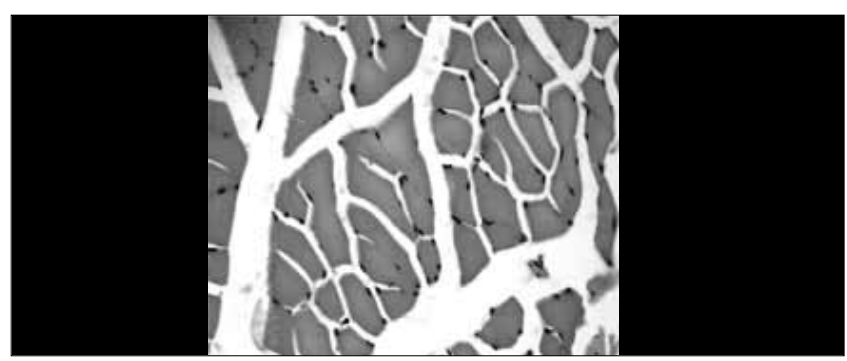

Figure 9. Effect of mesenchymal stem cells after 30 days from injection in myopathic rat, on light microscopic findings: Transverse section from gastrocnemius muscle of group VIII ( $\operatorname{sim} 46 \mathrm{~d}$. with MSC on day 16) showing almost normal muscle fibres. TS, H.\&E.X400

Table 11. Effect of mesenchymal stem cells after 30 days from injection in myopathic rats, on serum myoglobin $(\mathrm{ng} / \mathrm{ml})$

\begin{tabular}{lcc}
\hline Groups $\mathrm{n}=10$ rats & \multicolumn{2}{c}{ Serum myoglobin $(\mathrm{ng} / \mathrm{ml})$} \\
& Mean \pm S.E.M & $\%$ change \\
\hline Gr. I Control & $0.13 \pm 0.008$ & \\
Gr. VII sim.46 d. & $0.83^{\mathrm{a}} \pm 0.064$ & $+552.4 \% \mathrm{a}$ \\
$\mathrm{Gr}$. VIII & $0.11^{\mathrm{b}} \pm 0.01$ & $-86.9 \% \mathrm{~b}$ \\
$\left(\right.$ Sim. 46 d with MSC at $\left.16^{\text {th }} \mathrm{d}.\right)$ & \\
\hline $\mathrm{n}=$ number of rats in each group & \\
By ANOVA: $\mathrm{F}=133.8, \mathrm{P}<0.0005$ & \\
By Bonferroni Test: & \\
$\mathrm{a}=\mathrm{P}<0.0005$ vs Gr. I (control) & \\
$\mathrm{b}=\mathrm{P}<0.0005$ vs. Gr. VII (sim. 46) & \\
\hline
\end{tabular}

between our study and thpse of Pierno et al. $(11,19)$ may be related to the different statin used, different doses and durations. Much higher doses may be required to induce histological modifications. There is also similarity between the present results and those reported by Nakahara et al. (20), where administration of simvastatin $50 \mathrm{mg} / \mathrm{kg} / \mathrm{day}$ for 4 weeks in 6 rabbits showed muscle necrosis with high serum ck in some of them.

The results of the present work are also in agreement, to a great extent, with many studies carried on human patients receiving various types of statins for variable durations. Carvalho et al. (21) reported ck elevatation in patients with statin induced myopathy. Guis et al. (22) also observed increased ck levels in patients who were administered statin. This denoted that $\mathrm{ck}$ is considered as a useful parameter in tracing myopathy in statin users including those who are asymptomatic (23).

Statins cause myopathy which is reversible upon cessation of the drug (24). Generally, this reversibility includes the myopathic signs and symptoms of tenderness, myalgias, cramping and elevated serum ck activity $(25,26,27)$. The present results showed that discontinuing simvastatin for 14 and 30 days following induction of myopathy caused marked improvement in EMG findings in all rats. The EMG findings were characterized by longer durations and polyphasity indicating regeneration, when compared to severe myopathic changes in rats received simvastatin for 16 days. However, the persistence of these mild myopathic changes after simvastatin cessation indicated partial recovery. The improvement in EMG was accompanied by significant reduction in serum $\mathrm{ck}$ and myoglobin levels with their returning almost back to normal. In addition, no significant changes were shown 30 days after simvastatin was discontinued when compared with that after 14 days.

There was also improvement in the light microscopic findings 14 and 30 days after simvastatin was discontinued, when compared to severe myopathic changes in rats that received simvastatin for 16 days. The most prominent feature in most sections was muscle regeneration, in the form of hypercellularity with numerous nuclei.

In agreement with the present results, Mohaupt et al. (23) , Soininen et al. (28) and Hansen et al. (29) observed that following cessation of statins, resolution of muscle symptoms and normalization of ck levels were noted within a few weeks in most patients who showed an elevated ck with statin induced myopathy. The recovery of statin induced myopathy reported in the present study, after statin withdrawal, could be explained by the normal regenerative capacity of adult skeletal muscle. This regenerative response is due to the presence of resident stem cell populations, mainly satellite cells, beside side population cells and other potential progenitor cell populations (30). 
Satellite cells are supplemented throughout life by cells derived from bone marrow (both hematopoietic and mesenchymal). These cells are mobilized and trafficked during exercise, injuries and probably other conditions. Initially, BMderived cells settle in the interstitial tissue in the neighborhood of blood vessels and display relatively low myogenic potential. But the changes occur in the environment of regenerating muscle, enhance myogenic determination, so, with time, cells derived primarily from bone marrow or their progeny can enter satellite cells position and begin to express markers of myogenic precursors $(31,32)$. Consistent with that, Ramirez et al. (33) reported that both acute and chronic injury of muscle resulted in mobilization of mesenchymal stem cells from bone marrow to the peripheral blood. In addition, circulating bone marrow-derived cells were able to settle in skeletal muscle and contribute to their regeneration $(34,35)$. Stem cell transplantation therapy may offer a promising approach to enhance the regenerative ability of damaged and degenerated skeletal muscle either after injury or as a consequence of diseases such as muscular dystrophy (36).

The results of this research supported the therapeutic role of MSC in management of induced myopathy. The injected cells homed to the site of injury as evidenced by detection of $y$ chromosome marker, of male derived stem cells, in injured female gastrocnemius muscles. Furthermore, following MSC injection there was marked improvement of myopathic features, despite continuation of simvastatin administration.

There was significant improvement in EMG findings, characterized by increase in amplitude, prolongation of duration and polyphasity that indicated regeneration, when compared to severe myopathic changes in groups received simvastatin only. The improvement recorded 30 days after MSCs injection, was significantly better than that observed after 14 days., There was also significant decrease in both serum ck and serum myoglobin levels with these levels returning almost back to normal within 14 and 30 days after MSC injection.

At the same time, the light microscopic findings were markedly improved within 14 and 30 days after MSC injection with more improvement after 30 days. The most prominent feature is muscle regeneration, in the form of hypercellularity with numerous nuclei, and many sections returned almost completely normal.

Similar results to that of the present study reported by many researchers. They tried to study the effects of different types of stem cells in management of skeletal muscle injury and its regeneration. Feng et al. (9) transplanted rat bone marrow derived MSC labeled with radioactive substance to irradiated mdx mice via intravenous injection. A percentage of infused cells homed to bone marrow, as it is the origin of MSC and pre-transplantation chemotherapy or irradiation of $\mathrm{BM}$ often increases the homing of infused cells. Subsequently mesenchymal progenitors expanded and migrated to damaged skeletal muscles, as evidenced by increased radioactive concentration (37). Bittner et al. (38) demonstrated the recruitment and homing of $\mathrm{BM}$ cells to dystrophic but not normal muscle. Francois et al. (39) also demonstrated increased recruitment and homing of donor cells to tissues subjected to irradiation injury in immunodeficient mice. All these results are consistent with the present study that showed homing of MSC in myopathic muscles.In addition, Dezawa et al. (40) has demonstrated that infused GFP-labeled human MSC are detected in dystrophic muscles of $\mathrm{mdx}$ mice rather than nondamaged muscles and other tissues in the immunosuppressed rats. Also they observed regeneration of damaged skeletal muscles by BM-derived MSC. Feng et al. (9) demonstrated gradual increase of dystrophin-positive myofibres in skeletal muscle of $\mathrm{mdx}$ mice received BM-derived MSC. However, serum ck and percentage of centrally nucleated fibres CNF decreased slightly after transplantation, indicating partial recovery. This is in agreement with the present study which showed incomplete recovery of simvastatin induced myopathy 30 days after MSC transplantation, where EMG results showed mild myopathic changes. Moreover, by using a model of CTX induced skeletal muscle damage, with transplantation of bone marrow cells labeled by GFP, Abedi et al. (7) showed that GFP + muscle fibres appeared in host mice after 14 days and were maximized 4 weeks after transplantation, in a way that greatly support the results of the present thesis.

There are many articles proved that injury is the main influence of homing of stem cells $(38,39)$. This may explain that although in the present study, cells were transplanted after occurrence of injury, but good results were obtained that proved homing of injected stem cells to the injured site. Drapeau et al. (41) proved that BMSC have the ability to migrate to injured skeletal muscle and hence participate in its regeneration. RosuMyles et al. (42) and Kucia et al. (43) tried to determine the mechanism of stem cells mobilization and their homing to the injured muscle tissue. They recognized that damaged muscle release signals (chemokines, growth factors), which, on the basis of chemical gradient, attract circulating stem cells to the injured area.

It has been suggested that marrow cells homed to injured muscle follow a biological progression first forming satellite cells then fusing to form mature myofibres (44).

We concluded that MSC injection in myopathic rats caused improvement of skeletal muscle function with pronounced regeneration, in spite of continuous simvastatin administration. Skeletal muscle regeneration is not an infinite process and there is exhaustion of endogenous stem cells in pathological states resulting in failure of regenerative response. Consequently, if circulating stem cells, especially MSC are increased by exogenous transplantation, the regenerative process might be facilitated. 


\section{References}

1. Kassem M, Abdallah BM. Human bone-marrow-derived mesenchymal stem cells: biological characteristics and potential role in therapy of degenerative diseases. Cell Tissue Res 2008;331:157-63.

2. Lo B, Parham L. Ethical issues in stem cell research. Endocrine Reviews 2009;30:204-13.

3. Gang EJ, Darabi R, Bosnakovski D, Xu Z, Kamm KE, Kyba M, et al. Engraftment of mesenchymal stem cells into dystrophin-deficient mice is not accompanied by functional recovery. Exp Cell Res 2009;315:2624-36.

4. Hentze H, Graichen R, Colman A. Cell therapy and the safety of embryonic stem cell-derived grafts. Trends Biotechnol 2007;25:24-32.

5. Weiss DJ, Berberich MA, Borok Z, Gail DB, Kolls JK, Penland C, et al. Adult stem cells, lung biology and lung disease. Proc Am Thorac Soc 2006;3:193-207.

6. Tedesco FS, Dellavalle A, Diaz-Manera J, Messina G, Cossu, G. Repairing skeletal muscle: regenerative potential of skeletal muscle stem cells. J Clin Invest 2010;120:11-9.

7. Abedi M, Foster BM, Wood KD, Colvin GA, McLean SD, Johnson KW, et al. Haematopoietic stem cells participate in muscle regeneration. Br J Haematol 2007;138:792-801.

8. Bobis S, Jarocha D, Majka M. Mesenchymal stem cells: characteristics and clinical applications. Folia Histochem Cytobiol 2006;44:215-30.

9. Feng SW, Lu XL, Liu ZS, Zhang YN, Liu TY, Li JL, et al. Dynamic distribution of bone marrow-derived mesenchymal stromal cells and change of pathology after infusing into mdx mice. Cytotherapy 2008;10:254-64.

10. Jasinska M, Owczarek J, Orszulak-Michalak D. Statins: a new insight into their mechanisms of action and consequent pleiotropic effects. Pharmacol Rep 2007;59:483-99.

11. Pierno S, Camerino GM, Cippone V, Rolland JF, Desaphy JF, De Luca A, et al. Statins and fenofibrate affect skeletal muscle chloride conductance in rats by differently impairing $\mathrm{ClC}-1$ channel regulation and expression. $\mathrm{Br} \mathrm{J}$ Pharmacol 2009;156:1206-15.

12. Amato, A.A. and Russell, J.A. Neuromuscular disorders. McGraw-Hill Companies, New York, Chicago and San Francisco: 2008:17-99, 529-763.

13. Rosenson, R.S. Current overview of statin induced myopathy. Am J Med 2004;116:408-16

14. Rochefort GY, Vaudin P, Bonnet N, Pages JC, Domenech J, Charbord P, et al. Influencing of hypoxia on the domiciliation of mesenchymal stem cells after infusion into rats: possibilities of targeting pulmonary artery remodeling via cells therapies? Respir Res 2005;6:125.

15. Davidson $\mathrm{MH}$, Robinson JG. Safety of aggressive lipid management. J Am Coll Cardiol 2007;49:1753-62.

16. Westwood FR, Bigley A, Randall K, Marsden AM, Scott RC. Statin-induced muscle necrosis in the rat: distribution, development, and fibre selectivity. Toxicol Pathol 2005;33:246-57.

17. Sidaway J, Wang Y, Marsden AM, Orton TC, Westwood FR, Azuma CT, et al. Statin-induced myopathy in the rat: relationship between systemic exposure, muscle exposure and myopathy. Xenobiotica 2009;39:90-8.

18. Mallinson JE, Constantin-Teodosiu D, Sidaway J, Westwood FR, Greenhaff PL. Blunted Akt/FOXO signalling and activation of genes controlling atrophy and fuel use in statin myopathy. J Physiol 2009;587:219-30.

19. Pierno S, Didonna MP, Cippone V, De Luca A, Pisoni M, Frigeri A, et al. Effects of chronic treatment with statins and fenofibrate on rat skeletal muscle: a biochemical, histological and electrophysiological study. Br J Pharmacol 2006;149:909-19.

20. Nakahara K, Kuriyama M, Sonoda Y, Yoshidome H, Nakagawa H, Fujiyama J, et al . Myopathy induced by HMG-CoA reductase inhibitors in rabbits: a pathological, electrophysiological, and biochemical study. Toxicol Appl Pharmacol 1998;152:99-106.

21. Carvalho AA, Lima UW, Valiente RA. Statin and fibrate associated myopathy: study of eight patients. Arq Neuropsiquiatr 2004;62:257-61.

22. Guis, S., Figarella-branger, D., Mattei, J. P., et al . In vivo and in vitro characterization of skeletal muscle metabolism in patients with statin-induced adverse effects. Arthritis Rheum 2006;55 551-557.
23. Guis S, Figarella-Branger D, Mattei JP, Nicoli F, Le Fur Y, Kozak-Ribbens G, et al. Association between statin-associated myopathy and skeletal muscle damage. CMAJ 2009;181:E11-8.

24. Needham M, Fabian V, Knezevic W, Panegyres P, Zilko P, Mastaglia FL. Progressive myopathy with up-regulation of MHC-I associated with statin therapy. Neuromuscul Disord 2007;17:194-200.

25. Baker SK, Tarnopolsky MA. Statin-associated neuromyotoxicity. Drugs Today (Barc) 2005;41:267-93.

26. Ucar M, Mjörndal T, Dahlqvist R. HMG CoA reductase inhibitors and myotoxicity. Drug Saf 2000;22:441-57.

27. Thompson PD, Clarkson P, Karas RH. Statin-Associated Myopathy. JAMA 2003;289:1681-90.

28. Soininen K, Niemi M, Kilkki E, Strandberg T, Kivistö KT. Muscle Symptoms Associated with Statins: A Series of Twenty Patients. Basic Clin Pharmacol Toxicol 2006;98:51-4.

29. Hansen KE, Hildebrand JP, Ferguson EE, Stein JH. Outcomes in 45 patients with statin-associated myopathy. Arch Intern Med 2005;165:2671-6.

30. Martin CM, Hawke TJ, Garry DJ. Stem Cells and Muscle Regeneration. In: Principles of Molecular Medicine. 2rd ed. Runge MS, Patterson C, Eds. Humana Press Inc: Totowa NJ 2006:682-87.

31. Seale P, Ishibashi J, Scimè A, Rudnicki MA. Pax7 is necessary and sufficient for the myogenic specification of CD $45+$ : Sca1 + stem cells from injured muscle. PLoS Biol 2004;2:664-72.

32. Burdzińska A, Gala K, Paczek L. Myogenic stem cells. Folia Histochem Cytobiol 2008;46:401-12.

33. Ramírez M, Lucia A, Gómez-Gallego F, Esteve-Lanao J, Pérez-Martínez A, Foster C, et al. Mobilization of mesenchymal cells into blood in response to skeletal muscle injury. Br J Sports Med 2006;40:719-22.

34. Majka SM, Jackson KA, Kienstra KA, Majesky MW, Goodell MA, Hirschi KK. Distinct progenitor populations in skeletal muscle are bone marrow derived and exhibit different cell fates during vascular regeneration. J Clin Invest 2003;111:71-9.

35. Sherwood RI, Christensen JL, Conboy IM, Conboy MJ, Rando TA, Weissman IL, et al . Isolation of adult mouse myogenic progenitors: functional heterogeneity of cells within and engrafting skeletal muscle. Cell 2004;119:543-54.

36. Markert CD, Atala A, Cann JK, Christ G, Furth M, Ambrosio F, et al. Mesenchymal Stem Cells: Emerging Therapy for Duchenne Muscular Dystrophy. PM R 2009;1:547-59.

37. Bossolasco P, Corti S, Strazzer S, Borsotti C, Del Bo R, Fortunato F, et al. Skeletal muscle differentiation potential of human adult bone marrow cells. Exp Cell Res 2004;295:66-78.

38. Bittner RE, Schöfer C, Weipoltshammer K, Ivanova S, Streubel B, Hauser E, et al. Recruitment of bone marrow-derived cells by skeletal and cardiac muscle in adult dystrophic mdx mice. Anat Embryol (Berl) 1999;199:391-6.

39. François S, Bensidhoum M, Mouiseddine M, Mazurier C, Allenet B, Semont A, et al. Local irradiation not only induces homing of human mesenchymal stem cells at exposed sites but promotes their widespread engraftment to multiple organs: a study of their quantitative distribution after irradiation damage. Stem Cells 2006;24:1020-9.

40. Dezawa M, Ishikawa H, Itokazu Y, Yoshihara T, Hoshino M, Takeda S, et al. Bone marrow stromal cells generate muscle cells and repair muscle degeneration. Science 2005;309:314-7.

41. Drapeau C, Antarr D, Ma H, Yang Z, Tang L, Hoffman RM, et al. Mobilization of bone marrow stem cells with StemEnhancer improves muscle regeneration in cardiotoxin-induced muscle injury. Cell Cycle 2010;9:1819-23.

42. Rosu-Myles M, Stewart E, Trowbridge J, Ito CY, Zandstra P, Bhatia M. A unique population of bone marrow cells migrates to skeletal muscle via hepatocyte growth factor/c-met axis. J Cell Sci 2005;118:4343-52.

43. Kucia M, Wojakowski W, Reca R, Machalinski B, Gozdzik J, Majka M, et al. The migration of bone marrow-derived non-hematopoietic tissue- committed stem cells is regulated in an SDF-1-, HGF-, and LIF-dependent manner. Arch Immunol Ther Exp (Warsz) 2006;54:121-35.

44. LaBarge MA, Blau HM. Biological progression from adult bone marrow to mononucleate muscle stem cell to multinucleate muscle fiber in response to injury. Cell 2002;111:589-601. 